JOLANTA SAJDERA

Uniwersytet Pedagogiczny w Krakowie, Polska - Pedagogical University of Krakow, Poland

\title{
Inicjatywy przedsiębiorcze na rzecz edukacji z perspektywy działalności Ogólnopolskiej Sieci Zagród Edukacyjnych
}

\section{Entrepreneurial Initiatives for Education Based on the Example of the Activities of the Educational Farm Network}

\begin{abstract}
Streszczenie: Problematyka artykułu dotyczy dylematów rozwoju przedsiębiorczości w aspekcie aktywności człowieka wspieranej inicjatywami jednostek samorządu terytorialnego i państwa. Artykuł koncentruje się na aktywności przedsiębiorczej podejmowanej na rzecz edukacji przez podmioty niezwiązane z oświatą. Pierwsza część tekstu prezentuje działalność Ogólnopolskiej Sieci Zagród Edukacyjnych (OSZE) finansowanej w ramach Programu Rozwoju Obszarów Wiejskich na lata 2014-2020. Na podstawie analizy literaturowej materiałów źródłowych zaprezentowano etapy wyłonienia się inicjatywy OSZE (marka zarejestrowana w Urzędzie Patentowym RP w 2014 r.). W drugiej części tekstu zwrócono uwagę na dylematy wspierania inicjatyw w zakresie usług edukacyjnych z perspektywy pedagoga-eksperta szkoleniowego współpracującego z OSZE. Dokonano analizy treści oferty edukacyjnej 278 zagród funkcjonujących aktualnie w Polsce w kontekście założeń podstawy programowej ogłoszonej przez Ministerstwo Edukacji Narodowej (MEN) w 2017 r. Wyniki analiz ukazują potencjał obszarów wiejskich jako alternatywnego miejsca edukacji w środowisku „małej ojczyzny”, a zarazem gotowość mieszkańców wsi do innowacji przedsiębiorczych w zakresie usług społecznych. W podsumowaniu artykułu podjęto refleksję nad koniecznością dalszych badań związanych ze wsparciem merytorycznym właścicieli zagród edukacyjnych w podnoszeniu jakości oferowanych przez nich usług edukacyjnych dla potencjalnych adresatów oferty, którymi są dzieci i młodzież.
\end{abstract}

\begin{abstract}
The paper focuses upon the dilemmas of entrepreneurship development in the aspect of human activity supported by initiatives of local government units and the state. The aim of the article is to draw attention to entrepreneurial activity undertaken for education by entities not related to education. The first part of the text presents the activities of the Educational Farm Network (EFN). Based on the analysis of the content of the source materials, the stages of the emergence of the EFN initiative (brand registered in the Patent Office of the Republic of Poland in 2014) were presented. The second part of the text highlights the dilemmas of supporting initiatives in the field of educational services from the perspective of an educator-training expert cooperating with EFN. The content of the educational offer of 279 units of educational farm was analysed in the context of the MEN 2017 - the curriculum program
\end{abstract}


base. The results of the analysis show the potential of rural areas as an alternative place of education in the "small homeland" environment and at the same time the readiness of rural inhabitants to undertake entrepreneurial innovations in the field of social services. In the summary of the article a reflection was made on the need for further research related to providing the substantive support to the owners of educational farms in the scope of improving the quality of educational services offered to children and the youth who are potential recipients of the offer.

Słowa kluczowe: inicjatywy społeczne; przedsiębiorczość w środowisku wiejskim; usługi edukacyjne; zagroda edukacyjna

Keywords: educational farm; educational services; entrepreneurship in a rural environment; social initiatives

Otrzymano: 3 stycznia 2020

Received: 3 January 2020

Zaakceptowano: 30 czerwca 2020

Accepted: 30 June 2020

\section{Sugerowana cytacja/Suggested citation:}

Sajdera, J. (2020). Inicjatywy przedsiębiorcze na rzecz edukacji z perspektywy działalności Ogólnopolskiej Sieci Zagród Edukacyjnych. Przedsiębiorczość - Edukacja [Entrepreneurship Education], 16(2), 214-224. doi: 10.24917/20833296.162.17

\section{Wstęp}

Aktywność przedsiębiorcza człowieka w kontekście jego zachowań ekonomicznych jest interesującym zagadnieniem ze względu na różnorodne obszary, w których ujawnia się gotowość do podejmowania inicjatyw na rzecz środowiska społecznego. Jak zauważa K. Wach, wzrasta zainteresowanie interdyscyplinarnością zjawiska przedsiębiorczości, także w kontekście znaczenia edukacji w zakresie przedsiębiorczych przedsięwzięć (enterprises education, por. Wach, 2014: 26). Celem niniejszego artykułu jest analiza inicjatyw przedsiębiorczych sytuowanych na styku gospodarki i edukacji (Wach, 2015: 25) na przykładzie działalności Ogólnopolskiej Sieci Zagród Edukacyjnych (OSZE). Wybór przedmiotu analiz wynika z doświadczeń współpracy autorki w charakterze eksperta szkoleń pedagogicznych z pomysłodawcą i liderem projektu - Centrum Doradztwa Rolniczego (CDR) w Brwinowie, oddział w Krakowie, a także z wyjątkowości samej inicjatywy realizowanej przez „przedsiębiorców wiejskich” (Gabińska, 2012: 259).

Na podstawie analizy literatury przedmiotu można stwierdzić, że funkcjonowaniem zagród edukacyjnych interesują się przede wszystkim badacze aktywności ekonomicznej społeczności lokalnych. Zakładanie zagród opisywane jest z punktu widzenia innowacyjności w zakresie produktu oraz działań przedsiębiorczych. Przykładami pierwszego ujęcia są badania zagród pod względem budowania markowego produktu turystyki wiejskiej (Bogusz, Wojcieszak, 2018), nowego produktu turystycznego (Mitura, Buczek-Kowalik, 2016) czy tematycznych produktów turystyki wiejskiej (Bajgier-Kowalska, Tracz, Uliszak, 2016). Z kolei aktywność przedsiębiorcza właścicieli zagród rozpatrywana jest w aspektach networkingu wiejskiej przedsiębiorczości (Kmita-Dziasek, Bogusz, 2017), innowacyjnej przedsiębiorczości na obszarach wiejskich Polski (Bogusz, Kania, 2016) czy innowacyjnego kierunku dywersyfikacji wiejskiej gospodarki (Czapiewska, 2018). 
Edukacyjny aspekt działalności zagród edukacyjnych rzadko jest tematem publikacji naukowych. Jeśli jest analizowany, to w kategoriach turystyki edukacyjnej (Sammel, 2017) czy wartości dodanej do oferowanych produktów lub usług (Czapiewska, 2018: 55). Innym sposobem analizy działalności zagród są badania z udziałem ich właścicieli (ankiety i wywiady), np. prowadzone przez M. Bogusz i E. Kmitę-Dziasek (2015). Autorki te interesowały się motywami podejmowania aktywności przedsiębiorczej w obszarze edukacji i wskazywały na pozaekonomiczne powody, którymi kierują się właściciele zagród: „Jak wynika z większości opisanych przypadków, działalność edukacyjna nie stanowi głównego czy nawet znacznego źródła dochodu. Mimo że zyski z edukacji stanowią niewielką część w strukturze dochodów, to właściciele nadal chcą rozwijać tę działalność, ponieważ dla każdego z nich jest to przede wszystkim pasja” (Bogusz, Kmita-Dziasek, 2015: 165). Podobne wnioski przyniosły szeroko zakrojone badania prowadzone przez zespół I. Sikorskiej-Wolak, K. Krzyżanowskiej i J. Zawadki (2018), który także przeprowadzał wywiady z właścicielami zagród. Wykazał on, że są to osoby przedsiębiorcze, zmotywowane do prowadzenia usług edukacyjnych z powodów pozazarobkowych, takich jak rozwijanie własnych pasji czy satysfakcja z pracy z dziećmi.

Zainteresowanie autorki niniejszego artykułu funkcjonowaniem OSZE wynika z podjętej przez nią w 2012 r. współpracy z krakowskim oddziałem CDR. Podczas kilku lat współpracy jako ekspert-pedagog z pomysłodawcami inicjatywy OSZE oraz uczestnikami szkoleń i warsztatów autorka koncentrowała się na działaniach związanych z podnoszeniem jakości oferty edukacyjnej tworzonej przez właścicieli zagród (Sajdera, 2015). Jest to zagadnienie warte refleksji ze względu na charakter aktywności przedsiębiorczej prowadzonej przez osoby niezwiązane $\mathrm{z}$ oświatą, a zatem usytuowane na styku gospodarki i edukacji nieformalnej.

Celem artykułu jest analiza treści oferty edukacyjnej 279 zagród edukacyjnych funkcjonujących aktualnie w Polsce. W części pierwszej autorka zaprezentowała proces wyłonienia się idei zagród edukacyjnych w naszym kraju na podstawie analizy literaturowej publikacji wydawanych przez CDR. Następnie przeanalizowała zasoby tekstowe (danych zastanych) portalu www.zagrodyedukacyjne.pl, dotyczące oferty edukacyjnej 279 zagród, szczególną uwagę poświęcając danym o osobach prowadzących zajęcia edukacyjne.

\section{Działalność Ogólnopolskiej Sieci Zagród Edukacyjnych}

Inicjatywa założenia OSZE ma swoje źródło w zainteresowaniach pracowników krakowskiego oddziału CDR w Brwinowie (m.in. Klimowska-Bobula i Dziasek-Kmita) doświadczeniami państw europejskich w zakresie edukacji na terenach wiejskich oraz potrzebą aktywizowania społeczności do rozwoju pozarolniczej działalności gospodarczej. Analiza materiałów ukazujących powstanie OSZE wskazuje na kilka czynników, które sprzyjały podjęciu tej inicjatywy. Przede wszystkim poszukiwano alternatyw dla funkcjonującego przez lata modelu polskiej agroturystyki wiejskiej, który nie wyczerpywał możliwości usług gospodarstw dla społeczeństwa (Bomba, Grojec, 2016). W ramach współpracy CDR ze Stowarzyszeniem Rolników Tessynskich (Unione Contadini Ticinesi e Segretariato Agricolo) w regionie Ticino w Szwajcarii zwrócono uwagę na rozbudowany program przygotowany w szwajcarskich gospodarstwach edukacyjnych zrzeszonych w SIF (Scuolla in Fattoria - Szkoła u Rolnika). Następnie w roku 2010 przeprowadzono sondaż wśród właścicieli 200 gospodarstw wiejskich w Polsce w celu zweryfikowania możliwości 
realizacji inicjatywy (Kmita-Dziasek, 2011). Oszacowanie potencjału zasobów gospodarstw pozwoliło krakowskiemu oddziałowi CDR we współpracy z Ministerstwem Rolnictwa i Rozwoju Wsi na rozpoczęcie w 2011 r. projektu „Utworzenie sieci agroturystycznych gospodarstw edukacyjnych w Polsce", a następnie na założenie OSZE w ramach Programu Rozwoju Obszarów Wiejskich na lata 2007-2013. Dalsza współpraca w zakresie dobrych praktyk ze Scuolla in Fattoria była rozwijana w ramach ogólnopolskiego projektu „Szwajcarskie gospodarstwa edukacyjne inspiracją dla innowacyjnych działań jednostek samorządowych w Polsce na rzecz zrównoważonego rozwoju obszarów wiejskich”, realizowanego przy wsparciu Funduszu Partnerskiego Grantu Blokowego dla Organizacji Pozarządowych i Polsko-Szwajcarskich Regionalnych Projektów Partnerskich Szwajcarsko-Polskiego Programu Współpracy.

Zainteresowanie funkcjonowaniem zagród edukacyjnych w środowiskach wiejskich rozwijane jest przez CDR od 2011 r. dzięki seminariom, w których wzięło udział 548 osób (Sammel, Jęczmyk, 2012: 397), oraz licznym szkoleniom i corocznym Ogólnopolskim Zlotom Zagród Edukacyjnych. Projekt OSZE realizowany jest od 2012 r. na terenie całego kraju. O jego atrakcyjności może świadczyć fakt, że sukcesywnie przystępują do niego kolejne gospodarstwa - w 2012 r. było zarejestrowanych 90 zagród, a w roku 2019 - już 278. Od kilku lat największa liczba zagród występuje w województwach: dolnośląskim, małopolskim i pomorskim (tabela 1).

Szczegółową charakterystykę działalności OSZE znaleźć można przede wszystkim w publikacjach wydawanych przez krakowski oddział CDR, który jest koordynatorem OSZE wraz z wojewódzkimi Ośrodkami Doradztwa Rolniczego oraz Ministerstwem Rolnictwa i Rozwoju Wsi. Od 2014 r. marka OSZE objęta jest ochroną prawną po zgłoszeniu jej do Urzędu Patentowego.

Na podstawie materiałów źródłowych można zauważyć, że formalne zasady regulaminu przystąpienia do OSZE (Centrum Doradztwa Rolniczego..., 2015) ukazują dążenie CDR do pobudzenia aktywności ekonomicznej osób, które nie tylko mieszkają na wsi, ale też prowadzą gospodarstwo rolne (uprawy rolne, hodowla zwierząt), co wynika z nadrzędnych założeń funkcjonowania CDR. W ramach działań na rzecz promowania pozarolniczej aktywności gospodarczej na obszarach wiejskich grupą docelową CDR w zakresie rozwijania przedsiębiorczości wiejskiej są „niewielkie gospodarstwa rolne produkujące głównie na własne potrzeby i funkcjonujące dzięki podejmowaniu działań dodatkowych, pracy dorywczej oraz wsparciu ze środków Unii Europejskiej [...], a także osoby "wychodzące« czy »wypchnięte« z rolnictwa [...]" (Bomba, Grojec, 2016: 5), co oznacza, że osoby zamieszkałe w miastach, które traktują teren rolniczy jako dodatkowe źródło dochodu (agroturystyka, hotelarstwo) lub formę rekreacji nie mogą prowadzić zagrody edukacyjnej.

Przystąpienie do OSZE jest bezpłatne, lecz uregulowane licznymi warunkami. Podstawowym warunkiem jest gotowość do przyjmowania dzieci i młodzieży w ramach programów szkolnych i aktywności pozaszkolnej w zakresie przynajmniej dwóch spośród zadań edukacyjnych dotyczących: produkcji roślinnej, produkcji zwierzęcej, przetwórstwa płodów rolnych, świadomości ekologicznej i konsumenckiej, dziedzictwa kultury materialnej wsi, tradycyjnych zawodów, rękodzieła i twórczości ludowej. Oferta edukacyjna musi być ujęta w programie zagrody dostępnym w portalu internetowym OSZE.

Koncepcja aktywizowania właścicieli gospodarstw rolnych na rzecz usług w zakresie edukacji sprzyja zmianie postawy wobec posiadanych zasobów materialnych 
gospodarstwa oraz własnych zasobów osobowych jako podstawy budowania ofert edukacyjnej, a także woli dalszego samokształcenia. Na ten aspekt uwarunkowania wewnętrznego rozwoju postaw przedsiębiorczych wskazują Z. Zioło i T. Rachwał (Zioło, Rachwał, 2019: 12).

W przypadku zagród można mówić o rozwijaniu inicjatyw przedsiębiorczych w środowisku wiejskim przez uwzględnianie zasobów obszarów wiejskich i ich walorów krajobrazowych dla celów pozarolniczych (Gabińska, 2012). Czynnikami rozwoju przedsiębiorczości o znaczeniu regionalnym i lokalnym w przypadku zagród są aspiracje lokalnej społeczności do tworzenia oferty edukacyjnej na terenach wiejskich oraz postawy przedsiębiorcze mieszkańców wsi wspierane i rozwijane przez CDR na terenie danej gminy. Pozyskiwane na ten cel fundusze pochodzą przede wszystkim ze środków unijnych, z Programu Rozwoju Obszarów Wiejskich na lata 2014-2020 Ministerstwa Rolnictwa i Rozwoju Wsi.

\section{Oferta edukacyjna jako produkt inicjatyw przedsiębiorczych} w zagrodach edukacyjnych

Oferentami „usług w zakresie edukacji” klasyfikowanych w dziale 85 PKWiU (Rozporzadzenie Rady Ministrów z dnia 12 grudnia 2017 r....) są publiczne i niepubliczne placówki oświatowe, a także osoby fizyczne decydujące się na zainwestowanie w działalność skierowaną do nauczycieli, uczniów i dzieci w wieku przedszkolnym. Wprowadzenie terminu „jakość oferty edukacyjnej” odnosi się do „usług”, których oferentami są nie tylko placówki oświatowe, ale też „klienci” z różnych grup wiekowych. Terminologia używana do definiowania oferty edukacyjnej, jak zauważa J. Madalińska-Michalak (2013: 14), nie wystarcza do opisu jej jakości ze względu na to, że specyfika usług edukacyjnych wymaga odmiennego podejścia do analizy jakości oferty $\mathrm{z}$ uwagi na charakter interakcji oferentnabywca. A zatem definiowanie oferty edukacyjnej zagród powinno uwzględniać relację między oferowanym produktami (wyrobami, usługami) a potencjalnymi odbiorcami, dysponującymi określonymi zasobami finansowymi (rodzice dzieci i uczniów). Analizując działalność zagrody jako miejsca edukacji, należy brać pod uwagę zarówno dostosowanie oferty do różnorodności potrzeb odbiorców, jak i sposób jej świadczenia przez właściciela.

W celu uzyskania wiedzy na temat oferty edukacyjnej autorka wykorzystała technikę analizy treści danych zastanych (Maj, 2013), prowadzoną w dwóch etapach: opisowym i kategoryzacyjnym. W etapie pierwszym autorka wyłoniła formalną konstrukcję danych tekstowych zawartych w bazie zagród edukacyjnych portalu zagrodaedukacyjna.pl. Baza danych w postaci wyszukiwarki pozwala zapoznać się z ofertą każdej zagrody, a struktura danych wynika z przyjętego wzoru kwestionariusza zgłoszenia obiektu, wypełnianego przez każdego właściciela. Na podstawie dokumentacji zgłoszeń obiektów baza zawiera następujące dane:

1. Realizowane cele edukacyjne: edukacja w zakresie produkcji roślinnej, produkcji zwierzęcej, przetwórstwa płodów rolnych, świadomości ekologicznej i konsumenckiej, dziedzictwa kultury materialnej wsi, tradycyjnych zawodów, rękodzieła i twórczości ludowej.

2. Tematyka oferowanych zajęć edukacyjnych: rolnictwo i zajęcia gospodarskie, przetwórstwo produktów spożywczych, tradycyjna żywność, kuchnia domowa, 
rękodzieło artystyczne, ginące zawody, zwyczaje i obrzędy, edukacja regionalna, ekologia, przyroda, zajęcia sportowe, zajęcia rekreacyjne.

3. Zakres oferty: Program jednodniowy/kilkudniowy, z noclegiem/bez noclegu, z wyżywieniem lub we własnym zakresie.

4. Adresaci oferty: dzieci w wieku przedszkolnym, szkoła podstawowa, szkoła średnia, studenci, osoby dorosłe, grupy specjalne.

5. Osoba prowadząca zajęcia edukacyjne: gospodarz, nauczyciel zatrudniony przez gospodarza, nauczyciel - opiekun grupy, inne osoby.

Po wyłonieniu konstrukcji formalnej analizowanych treści autorka wybrała jednostki analizy, koncentrując się na danych dotyczących osób prowadzących zajęcia edukacyjne. Jak wynika z tabeli 1, taką osobą w zagrodach był najczęściej gospodarz, w kilkunastu zagrodach był to także członek rodziny posiadający przygotowanie pedagogiczne. Co piąte gospodarstwo zatrudniało w tym celu nauczycieli (21\%), a co trzecie powierzało to działanie nauczycielowi, który przyjeżdżał z grupą (29\%). Porównując uzyskane dane z badaniami prowadzonymi przez innych badaczy (Bogusz, Kania, 2016; Sikorska-Wolak, Zawadka, 2016), można zauważyć, że wrasta liczba gospodarstw zatrudniających nauczycieli do prowadzenia zajęć.

Powierzanie prowadzenia zajęć nauczycielowi przyjeżdżającemu z grupą dotyczy zarówno sytuacji wcześniejszej współpracy ze szkołą, jak i specjalnych potrzeb grupy, np. osób niedowidzących.

Tabela 1. Liczba zagród edukacyjnych zatrudniających nauczycieli do prowadzenia zajęć w 2019 r.

\begin{tabular}{|l|c|c|c|}
\hline \multicolumn{1}{|c|}{ Województwo } & $\begin{array}{c}\text { Liczba zagród } \\
\text { ogółem }\end{array}$ & $\begin{array}{c}\text { Liczba zagród } \\
\text { zatrudniających } \\
\text { nauczycieli }\end{array}$ & $\begin{array}{c}\text { Liczba zagród, w których } \\
\text { zajęcia prowadził } \\
\text { nauczyciel przyjeżdżający } \\
\text { z grupą }\end{array}$ \\
\hline OGÓŁEM & 278 & 59 & 82 \\
\hline dolnośląskie & 38 & 6 & 10 \\
\hline małopolskie & 28 & 8 & 4 \\
\hline pomorskie & 24 & 8 & 12 \\
\hline mazowieckie & 23 & 5 & 5 \\
\hline śląskie & 21 & 5 & 5 \\
\hline świętokrzyskie & 19 & 3 & 6 \\
\hline warmińsko-mazurskie & 19 & 7 & 4 \\
\hline wielkopolskie & 19 & 3 & 4 \\
\hline podkarpackie & 17 & 2 & 5 \\
\hline kujawsko-pomorskie & 12 & 2 & 4 \\
\hline lubelskie & 12 & 1 & 1 \\
\hline opolskie & 12 & 1 & 5 \\
\hline podlaskie & 11 & 2 & 3 \\
\hline łódzkie & 9 & 2 & 3 \\
\hline lubuskie & 7 & 2 & 2 \\
\hline zachodniopomorskie & 7 & 2 & \\
\hline
\end{tabular}

Źródło: opracowanie własne na podstawie Bazy Zagród Edukacyjnych portalu www.zagroda-edukacyjna.pl (stan na 17 lipca 2020) 
Interesujące dane uzyskano, weryfikując kategorię „inne osoby prowadzące zajęcia edukacyjne”. Okazało się, że wśród wymienianych „innych osób” zwraca uwagę różnorodność profesji ludzi zapraszanych do współpracy. Byli wśród nich przedstawiciele zawodów tradycyjnych (np. mistrz plecionkarstwa, garncarz, pszczelarz), specjaliści nauk przyrodniczych (np. ornitolog), znawcy historii (np. kustosz muzeum), zawodowi instruktorzy (np. przewodnik górski, instruktor jazdy konnej), zooterapeuci (np. alpakoterapeuta) oraz twórcy ludowi (np. kapela regionalna). Ta wielość propozycji świadczyć może zarówno o gotowości do poszerzania oferty edukacyjnej, jak i o dobrej współpracy właścicieli zagród z lokalną społecznością w realizacji celów edukacyjnych. Można stwierdzić również, że zmienia się podejście właścicieli zagród do kompetencji osób prowadzących zajęcia edukacyjne.

Rozpowszechnianie inicjatyw przedsiębiorczych na rzecz edukacji jest mocną stroną przynależności do OSZE. Aktywizowanie osób prowadzących gospodarstwo rolne sprzyja zmianie postaw wobec posiadanych zasobów materialnych gospodarstwa oraz własnych zasobów osobowych jako podstawy budowania oferty edukacyjnej. Prowadzący zagrody przez swój udział w szkoleniach ukazują gotowość do samokształcenia umiejętności pedagogicznych, zgodnie z ideą wielowymiarowości kształcenia w zakresie miejsca i form organizowania edukacji. Oferta edukacyjna realizowana w gospodarstwie sprzyjać również może wyzwalaniu postaw przedsiębiorczych w młodym pokoleniu rodzin właścicieli zagród przez „doświadczenie przedsiębiorczości rodzinnej”, na co zwrócili uwage T. Rachwał i K. Wach podczas badań intencji przedsiębiorczych studentów kierunków nieekonomicznych (Rachwał, Wach, 2016: 411). Aktywizowanie właścicieli zagród dotyczy także współpracy z organizacjami pozarządowymi, instytucjami z otoczenia biznesu oraz samorządami lokalnymi przez propagowanie przedsiębiorczości na rzecz edukacji jako dobra wspólnego.

Działalność zagród nie powinna być rozumiana wyłącznie w kategoriach uczenia mimowolnego przez bezpośrednią dostępność środowiska naturalnego. Przygotowana oferta edukacyjna może przynieść wymierne korzyści edukacyjne w efekcie zaplanowanego procesu uczenia się poza instytucją oświatową, a więc „w” i „Z” codzienności (Muszyński, 2014: 82). W tym aspekcie istotne jest wsparcie osób przygotowujących i realizujących ofertę edukacyjną zagrody przez ich edukację w zakresie przedsiębiorczych przedsięwzięć (enterprises education), definiowaną jako wyposażanie w zdolności do generowania pomysłów oraz umiejętności niezbędnych do ich realizowania (Wach, 2014: 26).

Ze względu na to, że potencjalną grupą odbiorców oferty zagród są przede wszystkim dzieci i uczniowie (Sikorska-Wolak, Krzyżanowska, Zawadka, 2018), istotne jest rozwijanie u osób prowadzących zagrody kompetencji pedagogicznych, a nie tylko zarządczych, na co w 2007 r. zwracała uwagę B.M. Czarnecka (Czarnecka, 2007). Autorka apelowała wówczas o właściwe przygotowanie rolników do prowadzenia edukacji w zagrodzie wiejskiej i wskazała jako przykład szkolenia prowadzone w niemieckich landach czy wymóg certyfikowanego przygotowania pedagogicznego rolników w Austrii (Czarnecka, 2007: 50). Warto zauważyć, że publikacja Turystyka wiejska a edukacja, różne poziomy, różne wymiary, w której znalazł się tekst autorki, poprzedziła założenie OSZE. Obecnie można stwierdzić, że organizatorzy OSZE są zaangażowani w organizowanie różnych form wsparcia pedagogicznego od początku istnienia sieci. Na podstawie analizy tematycznej programów realizowanych podczas Ogólnopolskich Zlotów Zagród Edukacyjnych od 2014 r. można zauważyć włączanie zagadnień związanych z poszerzaniem wiedzy 
o rozwoju psychicznym dziecka (np. psychologia kreatywności, rozwój inteligencji), metodyką pracy z grupą (np. pedagogika zabawy) czy realizowaniem celów podstawy programowej MEN podczas zajęć w zagrodach.

Innym aspektem, na który zwróciła uwagę Czarnecka, jest wypracowanie celów edukacyjnych realizowanych w zagrodzie wiejskiej, które to cele autorka definiuje jako troskę o rozwijanie naturalnych zdolności do nauki i uczenia się osób uczestniczących w zajęciach w zagrodach oraz o trwałe wykorzystanie potencjału edukacyjnego zagrody (Czarnecka, 2007: 146).

Nawiązując do słów Czarneckiej, warto w tym miejscu zwrócić uwagę na dylematy związane $\mathrm{z}$ wykorzystaniem potencjału edukacyjnego zagród przez władze oświatowe w Polsce, który wynika z zapisów podstawy programowej MEN z 2017 r. (Rozporządzenie Ministra Edukacji Narodowej z dnia 14 lutego 2017 r....). Jak wynika z jej założeń, nauczyciel uczący przyrody, a następnie biologii i geografii w klasach IV-VIII powinien w swoim rocznym planie pracy uwzględnić częste wyjścia poza salę lekcyjną, czyli zajęcia w terenie. W najnowszym rozporządzeniu MEN z 2018 r. wśród dziesięciu celów krajoznawstwa i turystyki organizowanej przez szkoły wymieniono: „upowszechnianie wśród uczniów zasad ochrony środowiska naturalnego oraz wiedzy o składnikach i funkcjonowaniu rodzimego środowiska przyrodniczego, a także umiejętności korzystania z zasobów przyrody" (Rozporządzenie Ministra Edukacji Narodowej z dnia 25 maja 2018 r...., $\$ 2$, pkt. 5).

Jednak w opisie warunków i sposobów realizacji celów edukacji możemy przeczytać: „Większość proponowanych aktywności ucznia wymaga wyjścia z budynku szkolnego, lecz nie muszą to być dalekie wycieczki, wystarczy np. wyjście na boisko szkolne, drogę przed szkołą lub do parku” (Rozporzadzenie Ministra Edukacji Narodowej z dnia 14 lutego 2017 r...: 115). Ministerstwo promuje także „obiekty edukacyjne (izby/sale edukacyjne lub ośrodki edukacji leśnej) Lasów Państwowych”.

Publikacje powstające przy udziale Lasów Państwowych (www.lasy.gov.pl/pl/edukacja) ukazują możliwość realizowania celów podstawy programowej MEN w aspekcie ekosystemu leśnego, jednak nie wyczerpują możliwości edukacyjnych środowiska przyrodniczego dostępnego w zagrodach. Brak zainteresowania władz oświatowych działalnością zagród edukacyjnych wynikać może z potocznego myślenia o ich zasobach jako o miejscach wykorzystywanych tylko do rekreacji i promocji zdrowego żywienia (np. okazjonalne akcje MEN „Szkoła w ruchu”, „Ogród z klasą”). Tymczasem oferta edukacyjna zagród uwzględnia zbieżność celów edukacji (m.in. przyrodniczej) z możliwościami ich realizacji w zagrodach edukacyjnych zarówno w zakresie wiedzy deklaratywnej (znajomość pojęć i definicji zjawisk przyrodniczych, wiarygodne informacje o rzeczywistości przyrodniczej), jak i proceduralnej (kontakt ze zjawiskami przyrodniczymi w ich naturalnym środowisku, umiejętności związane z rozumnym wykorzystaniem zasobów przyrody przez człowieka). Szeroko rozumiana realizacja celów edukacyjnych zagrody wpisuje się w pełni w realizację podstawy programowej MEN, na co autorka niniejszego artykułu zwracała już uwagę (Sajdera, 2015). Łączenie wiedzy teoretycznej z zakresu przyrody ożywionej i nieożywionej z działaniami praktycznymi w zagrodach edukacyjnych umożliwia także przechodzenie od bezpośrednich kontaktów ze środowiskiem przyrodniczym do kształtowania wiedzy o tym środowisku, a także do rozwijania trzech podstawowych form aktywności człowieka: słownej, ruchowej i percepcyjnej w kontakcie z naturalnym środowiskiem przyrodniczym. Tym samym pobyt uczniów w zagrodach daje 
nauczycielom możliwość kontynuowania edukacji przedmiotowej w naturalnym środowisku, więc prawdziwej „zielonej szkoły”. Odwołując się do publikacji Czarneckiej (Czarnecka, 2007), można zatem podjąć próbę zdefiniowana działalności edukacyjnej zagrody w dwóch ujęciach: jako wycieczki przedmiotowej w formie edukacji nieformalnej, a jednocześnie produktu agroturystycznego, będącego wytworem działalności przedsiębiorczej. Wprowadzenie wymogu korzystania z „zielonych szkół w zagrodach” wymagałoby jednak wspólnego wypracowania rozwiązań systemowych przez MEN i Ministerstwo Rolnictwa. W tym względzie przykładem dobrych praktyk są rozwiązania szwajcarskie Krajowego Forum Schule auf dem Bauernhof, w którego składzie znajdują się reprezentanci Ministerstwa Rolnictwa i instytucji odpowiadającej za edukację na szczeblu krajowym oraz przedstawiciele rolników i nauczycieli (Kmita-Dziasek, Bogusz, 2017: 125).

\section{Podsumowanie}

Problematyka artykułu dotyczy aktywności przedsiębiorczej przejawiającej się w podejmowaniu inicjatyw społecznych w nowych obszarach działalności. Przykładem takich inicjatyw jest rozwijający się rynek usług w Polsce, którego struktura zmienia się dynamicznie, podążając za zmianami w życiu społecznym (tzw. proces serwicyzacji, Skórska, 2016). Rosnące zapotrzebowanie na różnego typu usługi edukacyjne dotyczy szerokiego grona odbiorców - od najmłodszych po seniorów. Edukacja prowadzona poza terenem placówki oświatowej wpisuje się w założenia idei lifelong learning, nieformalnego uczenia $\mathrm{w}$ różnych środowiskach. W Polsce stopniowo zwiększa się zainteresowanie środowiskiem przyrodniczym jako miejscem edukacji pozaformalnej dla całej rodziny (np. Pracownia Edukacji Żywej), jednak potrzeba włączenia działań w naturze do programów edukacyjnych nie jest realizowana w stopniu wystarczającym przez placówki oświatowe, pomimo argumentów naukowych pokazujących skutki braku kontaktu z naturą (tzw. syndrom deficytu natury). Szczególnie grupy dzieci w wieku przedszkolnym i wczesnoszkolnym są dostrzegane jako najważniejsi uczestnicy zajęć prowadzonych poza terenem placówki oświatowej. Na potencjał obszarów wiejskich warto spojrzeć z perspektywy alternatywnego miejsca edukacji w środowisku „małej ojczyzny”. Działania w naturalnym środowisku są niezbędnym komponentem samodzielnego weryfikowania wiedzy zawartej w podręcznikach czy w internecie, łączy się ponadto z możliwością poznawania dziedzictwa kulturowego danego regionu.

Na podstawie analizy działalności OSZE można stwierdzić, że projekt wyzwolił inicjatywy przedsiębiorcze na rzecz edukacji w środowiskach wiejskich całej Polski. Obecnie podejmowane są nowe intersujące inicjatywy, które aktywizują społeczności lokalne na rzecz bezrobotnych, dzieci z rodzin zastępczych i placówek opiekuńczych oraz osób niepełnosprawnych, czego przykładem jest Stowarzyszenie Gospodarstw Edukacyjnych Województwa Śląskiego założone w 2016 r. Z kolei nową inicjatywą krakowskiego oddziału CDR jest koncepcja rozwoju „gospodarstw opiekuńczych” w Polsce, kierowana m.in. „do osób niepełnosprawnych, osób opuszczających zakłady penitencjarne, osób uzależnionych, dzieci, młodzież, a także [...] osób starszych” (Działania na rzecz rozwoju...). Powyższe działania wpisują się w koncepcję rolnictwa społecznego - nowego spojrzenia na zrównoważony i wielofunkcyjny rozwój obszarów wiejskich. 
Literatura

References

Bajgier-Kowalska, M., Tracz, M., Uliszak, R. (2016). Uwarunkowania rozwoju przedsiębiorczości na obszarach wiejskich na przykładzie gospodarstw agroturystycznych województwa małopolskiego. Przedsiębiorczość - Edukacja [Entrepreneurship - Education], 12, 256-273.

Bogusz, M., Kania, J. (2016). Zagrody edukacyjne jako przykład innowacyjnej przedsiębiorczości. W: A. Jęczmyk, M. Maćkowiak, J. Uglis (red.), Turystyka wiejska. Zagadnienia ekonomiczne i marketingowe. Poznań: Wydawnictwo Wieś Jutra, 116-123.

Bogusz, M., Kmita-Dziasek E. (2015). Zagrody edukacyjne jako przykład innowacyjnej przedsiębiorczości na obszarach wiejskich. Studia Komitetu Przestrzennego Zagospodarowania Kraju PAN, 163, $155-166$.

Bogusz, M., Wojcieszak, M. (2018). Zagrody edukacyjne jako przykład markowego produktu turystyki wiejskiej. Intercathedra, 4(37), 329-334.

Bomba, J., Grojec, M. (2016). Rola Centrum Doradztwa Rolniczego w Brwinowie oraz jego oddziałów w rozwoju przedsiębiorczości wiejskiej. Problemy Drobnych Gospodarstw Rolnych, 2, 5-27. doi: 10.15576/PDGR/2016.2.5

Centrum Doradztwa Rolniczego w Brwinowie, Oddział w Krakowie. (2015). Regulamin Ogólnopolskiej Sieci Zagród Edukacyjnych. Pozyskano z: https://www.zagrodaedukacyjna.pl/dokumenty_2015/ regulamin_zagroda\%20edukacyjna_siec_2015.pdf

Czapiewska, G. (2018). Innowacyjność i aktywność społeczna w rozwoju obszarów wiejskich Pomorza przykład zagród edukacyjnych. Acta Universitatis Lodziensis Folia Geographica Socio-Oeconomica, 31, 39-58. doi: 10.18778/1508-1117.31.03

Czarnecka, B.M. (2007). Przygotowanie rolników do prowadzenia edukacji dzieci w ramach działalności agroturystycznej. W: J. Sikora (red.), Turystyka wiejska a edukacja - różne poziomy, różne wymiary. Poznań: Wydawnictwo AR, 144-154.

Działania na rzecz rozwoju gospodarstw opiekuńczych $w$ Polsce na poziomie regionalnym i lokalnym (2019; 5 listopada). Pozyskano z: http://www.gospodarstwa-opiekuncze.pl/

Gabińska, C.G. (2012). Kształcenie na rzecz przedsiębiorczości na obszarach wiejskich. Przedsiębiorczość - Edukacja [Entrepreneurship - Education], 8, 259-277.

Kmita-Dziasek, E. (2011). Agroturystyczne gospodarstwa edukacyjne - idee i dobre przykłady. Kraków: Centrum Doradztwa Rolniczego w Brwinowie Oddział w Krakowie.

Kmita-Dziasek, E., Bogusz, M. (2017). Networking wiejskiej przedsiębiorczości na przykładzie Ogólnopolskiej Sieci Zagród Edukacyjnych. W: J. Wojciechowska (red.), Sieci wspótpracy w turystyce wiejskiej. Stan obecny i nowe wyzwania. Centrum Doradztwa Rolniczego w Brwinowie Oddział w Krakowie: Kraków-Łódź, 115-133.

Madalińska-Michalak, J. (2013). Oferta edukacyjna i jakość kształcenia w publicznych liceach ogólnokształcacych $w$ Łodzi. Łódź: Wydawnictwo Uniwersytetu Łódzkiego.

Maj, A. (2013). Analiza treści. W: M. Makowska (red.), Analiza danych zastanych: przewodnik dla studenta. Warszawa: Wydawnictwo Naukowe Scholar, 127-147.

Mitura, T., Buczek-Kowalik, M. (2016). Zagroda edukacyjna jako nowy produkt turystyczny (przykład województwa podkarpackiego). Annales Universitatis Mariae Curie-Skłodowska. Sectio B, Geographia, Geologia, Mineralogia et Petrographia, 71(2), 117-128. doi: 10.17951/b.2016.71.2.117

Muszyński, M. (2014). Edukacja i uczenie się - wokół pojęć. Rocznik Andragogiczny, 21, 77-88. doi:10.12775/RA.2014.004

Rachwał, T., Wach, K. (2016). Badanie intencji przedsiębiorczych młodego pokolenia: wyniki ankietyzacji wśród studentów kierunków nieekonomicznych. Przedsiębiorczość - Edukacja [Entrepreneurship Education], 12, 405-415.

Rozporzadzenie Ministra Edukacji Narodowej z dnia 14 lutego 2017 r.w sprawie podstawy programowej wychowania przedszkolnego oraz podstawy programowej kształcenia ogólnego dla szkoły pod- 
stawowej, w tym dla uczniów z niepetnosprawnościq intelektualna $w$ stopniu umiarkowanym lub znacznym, kształcenia ogólnego dla branżowej szkoły I stopnia, kształcenia ogólnego dla szkoły specjalnej przysposabiającej do pracy oraz kształcenia ogólnego dla szkoły policealnej. Dz.U. z 2017, poz. 356.

Rozporzadzenie Ministra Edukacji Narodowej z dnia 25 maja 2018 r. w sprawie warunków i sposobu organizowania przez publiczne przedszkola, szkoły i placówki krajoznawstwa i turystyki. Dz.U.z 2018, poz. 1055.

Rozporządzenie Rady Ministrów z dnia 12 grudnia 2017 r. zmieniajace rozporządzenie w sprawie Polskiej Klasyfikacji Wyrobów i Ustug PKWiU. Dz.U. 2017, poz. 2453.

Sajdera, J. (2015). Edukacja w zagrodach edukacyjnych w kontekście dokumentów programowych wychowania przedszkolnego i kształcenia ogólnego. Kraków: Centrum Doradztwa Rolniczego w Brwinowie Oddział w Krakowie.

Sammel, A. (2017). Zagrody edukacyjne jako miejsce kształcenia osób dorosłych. Turystyka i Rozwój Regionalny, 7, 81-90.

Sammel, A., Jęczmyk, A. (2012). Usługi edukacyjne w gospodarstwach agroturystycznych zrzeszonych w sieci „Zagroda Edukacyjna”. Zeszyty Naukowe Uniwersytetu Szczecińskiego. Ekonomiczne Problemy Ustug, 722(95), 389-399.

Sikorska-Wolak, I., Zawadka, J. (2016). Edukacyjne funkcje gospodarstw rolnych. Studia Ekonomiczne i Regionalne, 9(2), 98-112.

Sikorska-Wolak, I., Krzyżanowska, K., Zawadka, J. (2018). Edukacja w turystyce wiejskiej. Warszawa: Wydawnictwo SGGW.

Skórska, A. (2016). Determinanty i perspektywy rozwoju sektora usług w Polsce - zmiany wewnątrzsektorowe. Prace Komisji Geografii Przemystu Polskiego Towarzystwa Geograficznego, 30(4), 7-20.

Wach, K. (2015). Przedsiębiorczość jako czynnik rozwoju społeczno-gospodarczego: przegląd literatury. Przedsiębiorczość - Edukacja [Entrepreneurship - Education], 11, 24-36.

Wach, K. (2014). Edukacja dla przedsiębiorczości: pomiędzy przedsiębiorczą pedagogiką a edukacją ekonomiczną i biznesową. Horyzonty Wychowania, 13(28), 11-31.

Zioło, Z., Rachwał, T. (2019). Zarys uwarunkowań dalszego rozwoju przedsiębiorczości w układach przestrzennych. Przedsiębiorczość - Edukacja, 15(1), 7-18.

Jolanta Sajdera, dr, adiunkt w Uniwersytecie Pedagogicznym im. Komisji Edukacji Narodowej w Krakowie, Wydział Nauk Społecznych, Instytut Pedagogiki Przedszkolnej i Szkolnej. Jej główne zainteresowania badawcze to urynkowienie instytucji edukacyjnych oraz wspieranie kompetencji społecznych i poznawczych w rozwoju dziecka.

Jolanta Sajdera, PhD, an assistant professor, Pedagogical University of Krakow, Faculty of Social Sciences. Her research interests focus on the marketisation of educational institutions and the support of social and cognitive skills in child development.

ORCID: https://orcid.org/0000-0002-7758-0117

\section{Adres/Address:}

Uniwersytet Pedagogiczny im. Komisji Edukacji Narodowej w Krakowie

Wydział Nauk Społecznych

Instytut Pedagogiki Przedszkolnej i Szkolnej

ul. Ingardena 4

30-060 Kraków, Poland

e-mail: jolanta.sajdera@up.krakow.pl 